\title{
Factors Contributing towards Studying Education Related Courses in Institutions in Kwara State, Nigeria: Implication on Teaching Profession
}

\author{
Habibat Abubakar Yusuf \\ Department of Educational Management \\ University of Ilorin \\ Ilorin, Nigeria \\ yusuf.ha@unilorin.edu.ng
}

\author{
Ismail Hussein Amzat \\ School of Education and Modern Languages, \\ College of Arts and Social Sciences, \\ University Utara Malaysia \\ Sintok, Malaysia
}

\author{
Khaliza Bint Saidin \\ School of Education and Modern Languages, \\ College of Arts and Social Sciences, \\ University Utara Malaysia \\ Sintok, Malaysia
}

\begin{abstract}
In the past, students admitted to study education related courses in the institutions are full of zeal and motivation to learn and practice as a full-fledged professional teacher. Unfortunately, there is a significant reverse in the scenario as pre-service teachers are not willing to practice in recent years. This paper examines the perception of pre-service teachers towards their career choice in studying education related courses in institutions in Kwara State, Nigeria. The factors in this study was grouped based on personal interest, referral, professional status and job-related factors. The correlational research of the survey type was used to gather information from the populationfrom the federal, state and private colleges of education in Kwara State. Some students totalling 220 were randomly selected from seven institutions to respond to the questionnaire items. The results indicated that participants have fractional attitude towards choosing teaching profession choice as many students were in the college due to referral. The paper therefore recommends the need to enhance and reward the practicing teachers with favourable condition of service to motivate younger ones coming into the profession.
\end{abstract}

Keywords-Students; Career; Teaching; Profession; Nigeria

\section{INTRODUCTION}

Historically, teacher education can be traced to the foundation of Western Education itself whereby missionary societies devoted their time and resources to the development of education and teacher training through Pupil-Teacher apprenticeship system before the Colonial Era in Nigeria. During this period, teachers recruited were further trained to receive daily instruction on teaching methodology for a period of two years from the head teacher, after which they were allowed to sit for pupil-teacher examination. This has enabled student-teachers to further receive education and training while they contribute to the educational demand of the society[1]. Consequently, the teacher education process developed significantly into a well-structured and complex one involving educational institutions in the training and developmental processes to equip teachers for better performance in their various responsibilities.

Over the centuries, teaching has been considered as the oldest and most noble of all professions in the history of mankind [2]. For instance, in Nigeria, history confirms that teachers occupied the position of great honour and influence in their communities [3]. Although, teachers have been regarded as a mainstay in the history of education, particularly in schools, yet the status of teaching remain a spring of confusion and contention across the world [4, 5]. Unfortunately, teacher retention has been a global challenge particularly in many African countries [6].

In a study of the determinants of teacher professionalism in Singaporean high school among 
338 teachers considering four factors of professional training, academic qualification, professional development and teaching experiences; remarkably, of all the factors identified, professional development was the only contributory factor in teacher professionalism [7]. Similarly, evidence from industrialized countries emphasizes that students of teacher with full professional preparation for teaching learn more than students of teacher with no professional preparation.

\section{WHAT IS EXPECTED OF A PROFESSIONAL TEACHER?}

Knowledgeable individuals who will in turn promote best practices and further unlock doors for prosperity cannot be over-emphasized [9]. The Merriam-Webster Dictionary defines teacher as one whose occupation is to instruct especially in the four walls of a classroom. By the way of contrast, the same dictionary describes Doctor as a physician, Dentist, or Veterinarian who is trained and licenced to practice. The same dictionary that define as teacher distinguish the profession from that of a Doctor with "LICENCE". The contrast in those two words trained and licenced sum up the problem of teaching profession in Nigeria. This generated a lot of controversies in our society and led to an unending question on how much education is required to be a professional teacher?

However, teaching profession in Nigeria have been handed a lot of criticisms of whether it is a profession or not. Critics of teaching profession have said that teaching lacks the germane characteristics of a viable profession, as certification and entrance into the profession is not strictly controlled by the set standards [10]. It is evident in the process of skill acquisition needed for practical knowledge and excellence which has resulted to deterrents in the professional status of teacher part of which include: irregular self-esteem of practicing teachers and the upcoming ones, porous entry qualification. Pressures emanating from society's perception of teaching career as however hindered both practicing teacher and student motivation to the profession [11]. Because of this, teachers may feel unappreciated and undervalued and may consider disengagement due to job dissatisfaction or forfeiting their job for something else [12,13]. Even though literature revealed several factors essentially required to operationalize teacher professionalism [14], fundamental issues like academic and professional qualification, professional development, job experience, commitment, recognition and confidence were identified in the distinctions [14, $15,16]$.

As an attempt to address these problems, it is imperative to investigate into the teaching profession as perceived by education students.Even though, students consider stereotype when making decision about quite a lot of careers, however, several research studies have been carried out in different countries of the world to understand factors responsible for students' choice of teaching as a profession. Researchers revealed that family interest, peer influence, cultural beliefs, role model and extrinsic reasons are part of the fundamental issues influencing student decision to choose teaching as a career $[17,18,19,20]$. Some of the factors cited varies across regions, for instance in Malaysia, cultural beliefs were identified to play a dominant role in facilitating the image of the teaching profession [21]; social influences were the key factors in the Turkish and Australian context); while socio-economic status was a significant factor in Zambia [22, 23]. Specifically, this study aimed to examine factor contributing to student choice of teacher education in Kwara State, Nigeria and to also examine their preparedness for teaching profession.

\section{METHOD}

This research followed the correlational study of the survey type to examine the perception of student on the teacher education programme in colleges of education in Kwara State. 220 colleges of education students who are currently on the teacher training programme were randomly selected across all institutions and faculties as participants in this study. A 28 items questionnaire adapted consisting of two sections were distributed among respondents [24]. The first section covers the demographic background of participants while the other part captures the overall objective of this study to examine student perception of teaching as a career choice with 4 option Likert-scale ranging from very unlikely (1) to very likely (4). The data was analysed using structural equation modelling to give answers to the hypotheses formulated in this study.

The success or failure of any nation can be traced to its education due to its place in nurturing various professionals who will man several sectors of the economy. Unarguably, teaching profession is indispensable in any society. Its ability to produce. 


\begin{tabular}{|c|c|c|c|}
\hline \multicolumn{2}{|c|}{ Demographic Variable } & \multirow{2}{*}{$\begin{array}{c}\begin{array}{c}\text { No of } \\
\text { Student }\end{array} \\
68\end{array}$} & \multirow{2}{*}{$\begin{array}{l}\text { (\%) } \\
31 \%\end{array}$} \\
\hline Sex & Male & & \\
\hline & Female & 152 & $69 \%$ \\
\hline \multirow{5}{*}{ 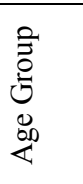 } & $<15$ years & 7 & $3 \%$ \\
\hline & $16-20$ years & 44 & $20 \%$ \\
\hline & $21-25$ years & 83 & $38 \%$ \\
\hline & $26-30$ years & 57 & $26 \%$ \\
\hline & $>30$ years & 29 & $13 \%$ \\
\hline \multirow{5}{*}{ 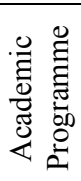 } & Diploma & 4 & $2 \%$ \\
\hline & Pre-NCE & 17 & $8 \%$ \\
\hline & Part Time NCE & 35 & $16 \%$ \\
\hline & Full Time NCE & 164 & $74 \%$ \\
\hline & Sandwich Degree & - & - \\
\hline \multirow{3}{*}{ 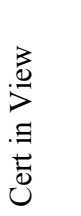 } & Professional Diploma in & 4 & $2 \%$ \\
\hline & Nigeria Certificate in & 216 & $98 \%$ \\
\hline & $\begin{array}{l}\text { Bachelor Degree in } \\
\text { Education }\end{array}$ & - & - \\
\hline \multirow{7}{*}{ 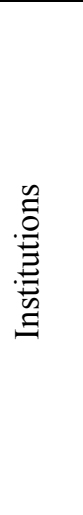 } & College of Education, & 67 & $30 \%$ \\
\hline & $\begin{array}{l}\text { Muhyideen College of } \\
\text { Education }\end{array}$ & 29 & $13 \%$ \\
\hline & $\begin{array}{l}\text { College of Education, } \\
\text { Lafiagi }\end{array}$ & 43 & $20 \%$ \\
\hline & College of Eduation, Oro & 45 & $20 \%$ \\
\hline & $\begin{array}{l}\text { Nigerian Army School of } \\
\text { Education }\end{array}$ & 10 & $5 \%$ \\
\hline & Kingsey College & 15 & $7 \%$ \\
\hline & $\begin{array}{l}\text { Education } \\
\text { College of Education, } \\
\text { Offa }\end{array}$ & 11 & $5 \%$ \\
\hline
\end{tabular}

\section{ANALYSIS OF DATA AND INTERPRETATION OF RESULTS}

This study involves survey whereby participants were requested to thick the most important factor they considered responsible or prompted their interest to have chosen teaching as a career, thiscomprise of four factors of personal interest consisting of 7 items, referral having 7 items, professional status having 7 items while job related factor consisting of 7 items. All sets of items related to these factors have been recoded and named for easier analysis and proper interpretation (See table 2).
TABLE 2 RELATED ITEMS

\begin{tabular}{|c|c|c|c|}
\hline Construct Name & Code & $\begin{array}{c}\text { Ite } \\
\mathrm{m} \\
\text { No }\end{array}$ & Description \\
\hline \multirow[t]{6}{*}{$\begin{array}{l}\text { Personal } \\
\text { Interest }\end{array}$} & Pint & PI1 & $\begin{array}{l}\text { Teaching is appropriate } \\
\text { for me. }\end{array}$ \\
\hline & & PI2 & $\begin{array}{l}\text { The idea of becoming a } \\
\text { teacher pleases me. }\end{array}$ \\
\hline & & PI3 & $\begin{array}{l}\text { I voluntarily chose the } \\
\text { teaching program I am } \\
\text { currently attending }\end{array}$ \\
\hline & & PI4 & I like teaching. \\
\hline & & PI5 & $\begin{array}{l}\text { It makes me happy to } \\
\text { think that I will become a } \\
\text { teacher. }\end{array}$ \\
\hline & & PI6 & $\begin{array}{l}\text { I am pleased with having } \\
\text { chosen this department } \\
\text { related to the teaching } \\
\text { profession. }\end{array}$ \\
\hline
\end{tabular}

PI7 I would like to work as a teacher even under difficult conditions.

\begin{tabular}{|c|c|c|c|}
\hline Construct Name & Code & $\begin{array}{l}\text { Item } \\
\text { No }\end{array}$ & Description \\
\hline \multirow[t]{7}{*}{ Referral } & Ref & RF1 & $\begin{array}{l}\text { My parent wants me to } \\
\text { teach. }\end{array}$ \\
\hline & & RF2 & $\begin{array}{l}\text { My friends think I } \\
\text { should choose } \\
\text { education course. }\end{array}$ \\
\hline & & RF3 & $\begin{array}{l}\text { My performance in } \\
\text { school made me choose } \\
\text { education. }\end{array}$ \\
\hline & & RF4 & $\begin{array}{l}\text { My parent's occupation } \\
\text { encouraged me to } \\
\text { choose teaching. }\end{array}$ \\
\hline & & RF5 & $\begin{array}{l}\text { Other } \\
\text { recommend } \\
\text { for me. }\end{array}$ \\
\hline & & RF6 & $\begin{array}{l}\text { My teachers believe I } \\
\text { have a special talent for } \\
\text { teaching. }\end{array}$ \\
\hline & & RF7 & $\begin{array}{l}\text { My counsellor at } \\
\text { school recommend } \\
\text { teaching for me. }\end{array}$ \\
\hline
\end{tabular}




\begin{tabular}{lccl}
\hline \multicolumn{1}{c}{$\begin{array}{c}\text { Construct } \\
\text { Name }\end{array}$} & Code & $\begin{array}{c}\text { Item } \\
\text { No }\end{array}$ & \multicolumn{2}{c}{ Description } \\
\hline $\begin{array}{l}\text { Professional } \\
\text { Status }\end{array}$ & PStat & PS1 & The nature of \\
& PS2 & $\begin{array}{l}\text { teaching profession } \\
\text { makes me feel secure }\end{array}$ \\
& & $\begin{array}{l}\text { I feel sure of the } \\
\text { requirements of the } \\
\text { teaching profession } \\
\text { Teaching profession } \\
\text { is at par with } \\
\text { medicine }\end{array}$ \\
& PS3 &
\end{tabular}

PS4 I believe I will be sufficiently esteemed by the society when I become a teacher.

PS5 I believe teaching will bring me a prestigious status in society.

PS6 I find it honourable to guide people's lives by working as a teacher

PS7 Teaching profession is well respected

\begin{tabular}{|c|c|c|c|}
\hline $\begin{array}{l}\text { Construct } \\
\text { Name }\end{array}$ & Code & $\begin{array}{l}\text { Item } \\
\text { No }\end{array}$ & Description \\
\hline \multirow[t]{7}{*}{$\begin{array}{ll}\text { Job related } \\
\text { factor }\end{array}$} & JFac & JF1 & $\begin{array}{l}\text { I choose teaching } \\
\text { because I can easily } \\
\text { get job when I } \\
\text { graduate. }\end{array}$ \\
\hline & & JF2 & $\begin{array}{l}\text { The working } \\
\text { conditions of the } \\
\text { teaching profession } \\
\text { attracts me. }\end{array}$ \\
\hline & & JF3 & $\begin{array}{l}\text { I think teaching will } \\
\text { provide me with } \\
\text { opportunities } \\
\text { beproductive } \\
\text { creative }\end{array}$ \\
\hline & & JF4 & $\begin{array}{l}\text { I can get well paid job } \\
\text { if I become a teacher }\end{array}$ \\
\hline & & JF5 & $\begin{array}{l}\text { I feel attracted to } \\
\text { people working as } \\
\text { teachers. }\end{array}$ \\
\hline & & JF6 & $\begin{array}{l}\text { Being a teacher has a } \\
\text { lot of prestige }\end{array}$ \\
\hline & & JF7 & $\begin{array}{l}\text { I choose teaching } \\
\text { because there will be } \\
\text { a great job demand for } \\
\text { teachers. }\end{array}$ \\
\hline
\end{tabular}

\section{Research Question - What factor is responsible for students' choice for teacher education programme?}

This study adopted Structural Equation Modelling (SEM) to examine the concurrent interactions among observed and latent variables in this study. SEM is one of the techniques for researchers across disciplines especially social sciences [25]. It is used in this study to represent a model which integrate all the factors mentioned (personal interest, referral, professional status, and job-related factors). The survey was done using 220 students who are currently undergoing teacher education programmes in colleges of education in Kwara State, Nigeria. The questionnaire for the survey was adapted from the study of [24]. The instrument was personally administered to students with the help of some lecturers who serve as research assistance in this study. The descriptive analysis shows that $31 \%$ of the respondents were male and $69 \%$ were female, many of which fall within the age bracket of 21-25 years, representing 38\%, $26-30$ years $(26 \%)$ and $16-20$ years $(20 \%)$ some of who are undertaking professional diploma in education $(2 \%)$ and pre-certificate in education (8\%). Many of the respondents offers different full and part time certificate in education programmes ( $74 \%$ and $16 \%$ respectively). Finally, all respondents were drawn from all colleges offering various teacher education programmes in the State (see table 1). Their responses captured all factors outlined in this study with a rating scale ranging from very unlikely (1), unlikely (2), somewhat likely (3) and very likely (4).

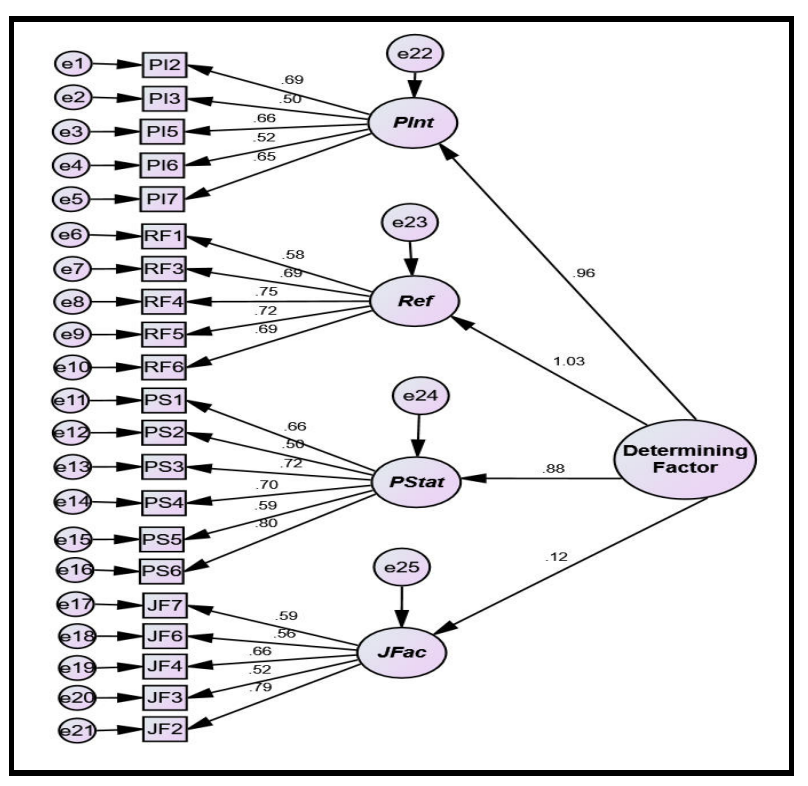

Fig. 1. Full Structural Model

$$
\begin{array}{ll}
\text { CMIN } & =3.12 \\
\text { CFI } & =0.92 \\
\text { TLI } & =0.90 \\
\text { RMSEA } & =0.06
\end{array}
$$


The measurement model was examined through a confirmatory factor analysis to estimate the factor with highest prediction of student choice. The model consists of all constructs and its corresponding indicators which was illustrated in table 2. From figure 1 above, the factor loadings for all constructs is $>.50$ after removing seven items that had very low loading from the model, leaving the remaining items at twenty-one. The results outputs in the model indicated a god fit of the model given a CMIN value of 3.12, CFI value of .924, TLI $=.907$, RMSEA $=.06$. All values obtained is in line with the recommended threshold [26], which undoubtedly justifies the fitness of data to the model. However, of all the factors outlined, referral is having the highest regression path coefficient value of 1.03 , which implies that many students of colleges of education were there due to advise from parents, friends, teachers or school counsellors (see figure 1).

\section{DISCUSSION OF FINDINGS}

The findings of this study revealed the perception of education student towards the programme. However, of all the factors predicting their choice, referral accounts for the highest predictor of student choice with the regression path coefficient value of 1.03 . Other factors like personal interest accounts for 0.96 and professional status account for 0.88 . responses from job related factor indicated that a very low value of 0.12 which implies that job factors like working conditions, job availability and opportunities does not determine student willingness to choose teaching as a profession but rather, their personal interest, their performance in high school, parental background and influence, recommendations by friends, teacher or school counsellor are all contributing factors that predicts the choice for studying education related courses in colleges of education in Kwara State.

\section{CONCLUSION}

Having consider the factors contributing to students' interest in studying education courses, referral accounted to the highest factor influencing it, which implies that, it is an important factor that should not be ignored. However, professional status should also be considered an important criterion that may influence high school leaving students to consider joining teaching profession, therefore, there is need to tailor much attention to professional development of the existing teachers to ensure outstanding personalities and courteous professional ethics of those in the teaching profession. On the other hand, many has not chosen the profession as a result job factor and it could be infer that, the working condition of the teachers is not encouraging and should therefore be addressed to make it attractive to the new ones. There is need to pay much attention to the problems associated with teacher welfare particularly those associated with the profession, such as salary and allowances, working environment and overall development that will complement their efforts.

\section{ACKNOWLEDGEMENTS}

This study was conducted in some selected federal, state and private colleges of education in Kwara State, Nigeria.

\section{REFERENCES}

[1] Ogunyinka, E. K., Okeke, T. I., \&Adedoyin, R. C. (2015). Teacher Education and Development in Nigeria: An Analysis of Reforms, Challenges and Prospects. Education Journal, 4(3), 111-122.

[2] Aklahyel, M. A., Ibrahim, M. I. \&Bawa, A. G. (2015). Teaching profession in Nigeria: Teacher professionalization is the way out. Standard Journal of Educational Research and Essay. Vol 3(10) pp. 344-348

[3] Arikawei, A. R., \&Benwari British, N. N. (2015). Regulatory challenges in the upgrading and maintenance of standards in teachers' professionalism in Nigeria. Journal of Education, 3(4), 48-57.

[4] Niyozov, S. (2008). Understanding teaching beyond content and method: Insights from Central Asia. European Education, 40(4), 46-69.

[5] Ingersoll, R. M., \&Perda, D. (2008). The status of teaching as a profession. Schools and society: A sociological approach to education, 107-118.

[6] Naseem, I., \& Salman, M. (2015). Measuring the Job Saticfactions Level of Academic Staff. Business \& Financial Affairs, 4(2), 3-6.

[7] Toh, K. A., Diong, C. H., Boo, H. K., \& Chia, S. K. (1996). Determinants of teacher professionalism. Journal of In-Service Education, 22(2), 231-244.

[8] Darling-Hammond, L. (2000). Teacher quality and student achievement. Education policy analysis archives, 8, 1.

[9] Nenty, H. J., Moyo, S., \&Phuti, F. (2015). Perception of teaching as a profession and UB teacher trainees' attitude towards training programme and teaching. Educational Research and Reviews, 10(21), 2797.

[10] Akinduyo, T. E. (2014). Teaching profession in Nigeria: Issues, problems and prospects. International Journal of Scientific and Research Publications, 4(11), 1-3.

[11] Nenty, H. J. (2010). Analysis of some factors that influence causal attribution of mathematics performance among secondary school students in Lesotho.

[12] Okeke, C. I., \&Mtyuda, P. N. (2017). Teacher Job Dissatisfaction: Implications for Teacher Sustainability and Social Transformation. Journal of Teacher Education for Sustainability, 19(1), 54-68.

[13] Okeke, C. I., \&Mtyuda, P. N. (2017). Teacher Job Dissatisfaction: Implications for Teacher Sustainability and Social Transformation. Journal of Teacher Education for Sustainability, 19(1), 54-68.

[14] Toh, K. A., Diong, C. H., Boo, H. K., \& Chia, S. K. (1996). Determinants of teacher professionalism. Journal of In-Service Education, 22(2), 231-244. 
[15] MacBeath, J. E. (2012). The future of the teaching profession. Brussells: Education International.

[16] Kerr, D. M., Kent, L., \& Lam, T. C. (1985). Measuring program implementation with a classroom observation instrument: The interactive teaching map.Evaluation Review, 9(4), 461-482.

[17] Manuel, J., \& Hughes, J. (2006). 'It has always been my dream': exploring pre-service teachers' motivations for choosing to teach. Teacher Development, 10(1), 5-24.

[18] Lovett, S. (2007). " Teachers of Promise": Is Teaching Their First Career Choice?

[19] Lai, K. C., Chan, K. W., Ko, K. W., \& So, K. S. (2005). Teaching as a career: A perspective from Hong Kong senior secondary students. Journal of Education for Teaching, 31(3), 153-168.

[20] Flores, M. A., \&Niklasson, L. (2014). Why do student teachers enrol for a teaching degree? A study of teacher recruitment in Portugal and Sweden. Journal of Education for Teaching, 40(4), 328-343.

[21] Azman, N. (2012). Choosing teaching as a career: Perspectives of male and female Malaysian student teachers in training. European Journal of Teacher Education, 36(1), 113-130.

[22] Watt, H. M., \& Richardson, P. W. (2007). Motivational factors influencing teaching as a career choice: Development and validation of the FIT-Choice scale. The Journal of experimental education, 75(3), 167-202.

[23] Richardson, P. W., \& Watt, H. M. (2005). 'I've decided to become a teacher': Influences on career change. Teaching and teacher education, 21(5), 475-489.

[24] Odia, J. O., \&Ogiedu, K. O. (2013). Factors affecting the study of accounting in Nigerian Universities. Journal of Educational and Social Research, 3(3), 89.

[25] Hooper, D., Coughlan, J., \& Mullen, M. (2008). Structural equation modelling: Guidelines for determining model fit. Articles, 2.

[26] Hair, J. F., Black, W. C., \&Babin, B. J. (2010). RE Anderson Multivariate data analysis: A global perspective 